\title{
Preliminary insight of information literacy competencies among school library media teachers
}

\author{
Shyh-Mee Tan and Singh Diljit \\ Library and Information Science Unit, Faculty of Computer Science and Information Technology, University of Malaya, 50603 \\ Kuala Lumpur, Malaysia. E-mail: shyhmee@ siswa.um.edu.my; diljit@um.edu.my
}

\begin{abstract}
This study examines library media teachers' perception of information literacy, their current levels of information literacy competencies, and the factors affecting information literacy implementation in secondary schools. 36 library media teachers from Selangor, Negeri Sembilan and Kuala Lumpur participated in this self-report questionnaire-based survey. Respondents knew what information literacy is and perceived it as much needed skills. Skills to identify information needed obtained a mean of 3.94 and skills to synthesize information scored the lowest mean of 3.47. They need continuing education opportunities, professional development, information literacy and LIS training. The country needs a national information agenda, policy and guidelines to implement information literacy.
\end{abstract}

\section{Introduction}

As the information world changes, the development of technology and information resources creates a vast range of information. It is becoming readily available in different forms, which in turn require different techniques to access and utilize this information. This contributes to diverse, complex, and excessive information in the education environment (Bruce, 2002; Pinto, Cordón, \& Gómez Díaz, 2010). The learning of information literacy skills becomes necessary in order for someone to be able to differentiate needed information from the vast information sources. Unfortunately, information literacy is still a new concept for developing countries. It tends to be confused with information communication and technology literacy. They know about information literacy concepts but are in need of more exposure and training in information literacy (Diao \& Chandrawati, 2005; Educational Technology Division, 2005; Norhayati, 2009).

At present, schools, as well as school libraries, are in many cases equipped with modern infrastructure and facilities, such as multimedia teaching courseware, computing facilities and internet connections, to enhance the students' academic achievement. However, in many places, the education system still emphasizes the traditional content based curriculum to determine students' achievement. The use of the available technology without clearly understanding and utilizing the information skills does not help students to become information literate, which is very necessary for lifelong learning (Combes, 2005). Information literacy, simply stated, is the ability to find the right information and knowing how to use it. Thus, the need of information literacy is crucial for students to learn and equip themselves with the skills and knowledge to distinguish valuable information from the unwanted. These skills are not innate but are to be learned and best inculcated to students by information literate library media teachers (Boekhorst, 2003; Henri, 2001; Horton, 2006; Ranaweera, 2008).

Various research studies have shown that library media teachers have expertise in pedagogy, information skills, knowledge of resources, teaching skills, providing in-service training to teachers, and managing an 'information portal' (Combes, 2005; Spence, 2005). They are ideally the key persons who have the overarching curriculum knowledge, the collaborative background, and ability to manage the curriculum resources across the school to provide the benefits of inculcating information literacy in secondary school students (Combes, 2005; Abrizah, 2008;).

The criterion for the selection of library media teachers were set in the Education Ministry circular, appendix $2 \mathrm{a}$ (2005). Although library media teachers are trained teachers, they still need to fulfill the requirement of having a minimum of three years teaching experience. Once their services are confirmed with at least three years of teaching experience, they are eligible to become library media teachers. The minimum library

(C) 2010 IASL, SLAQ and therein by the authors. Diversity Challenge Resilience: School Libraries in Action Proceedings of the $12^{\text {th }}$ Biennial School Library Association of Queensland, the $39^{\text {th }}$ International Association of School Librarianship Annual Conference incorporating the $14^{\text {th }}$ International Forum on Research in School Librarianship, Brisbane QLD Australia, 27 September - 1 October 2010 . 
science qualification required is the Basic Thirty-five Hours School Resource Centre Management Course and the highest qualification is the Masters' degree in Library and Information Science or Education Technology or Information Science Studies. However, these criterions are flexible. Teachers who do not have any basic library science qualifications would be recommended to attend the Basic Thirty-five Hours School Resource Centre Management Course followed by the Advance Forty-five Hours School Resource Centre Management Course prior to or subsequent to their appointment as library media teachers (Abrizah, 1999). Although there are, continuity courses such as the Fourteen Weeks and One Year In-Service School Resource Centre Management courses but these courses are non-compulsory courses. Moreover, qualified library media teachers who have attended these courses may not be guaranteed appointments as library media teachers in schools.

Library media teachers are key stakeholders in the implementation of information literacy. But how well equipped are these library media teachers themselves to implement information literacy? It is assumed that having gone through a library education programme, and perhaps some continuing education programmes, or self-development programmes, these library media teachers would be prepared to teach information literacy. Do they really understand the concept of information literacy? Are they familiar with the pedagogy of it? How well can they deliver it? These are among the questions that beg answers to ensure that these critical stakeholders are able to play their roles effectively.

\section{Statement of problem}

Library media teachers are important stakeholders in the Malaysian school system. They help to achieve the goals of information literacy in schools. However, teaching information literacy seems to be the responsibility of library media teachers but unfortunately, all information literacy activities are isolated from everyday classroom practices. The concept of information literacy has yet to become part of the curriculum unit or pedagogical issues (Chan, 2002). After all, information literacy is necessary in the building of a knowledge society. Information literacy education is a prerequisite for the attainment of information literacy status in all target groups. The recent and growing attention given to information literacy is timely, and policy makers in many countries have to be made aware of the state of information literacy practices in their countries (Educational Technology Division, 2005). However, Malaysia experiences the lukewarm situation without any proper proactive action to move ahead with implementations.

Other researchers emphasize the need to build a concept of information literacy in their nations. They aim to verify the presence of information skills in educational policy documents. To achieve this, it is necessary to change the school culture and the conception of learning and to improve the training of library media teachers and the information infrastructure (Campello, 2009). Thus, Norhayati (2009), asserted that the information literacy knowledge and implementation are minimal for them and the training of information literacy and implementation is not put into practice in Malaysia. Added to this, many library media teachers and principals are not aware of its importance and it is not yet used systematically and comprehensively in the schools (Diao \& Chandrawati, 2005). Therefore, indeed there is a gap to investigate how much library media teachers know about information literacy.

In the early days, the integration of information literacy into library media teacher preparation and development has not occurred. Library media teachers cannot prepare their students to be information literate unless they themselves understand how to find and use information. If they are to use information so that others can learn from them, then library media teachers must be information literate (Carr, 1998). As a result, many library media teachers often lack adequate information literacy skills and are unprepared to teach information literacy concepts and research strategies to their own students. Some library media teachers only have adequate information literacy skills in their own subject area, in one language. Their skills are not interdisciplinary. Therefore, library media teachers must be information literate if they are to effectively prepare students to actively participate in the education process (Boelens, 2006; Duke \& Ward, 2009).

Further research in local scenario finds that the library media teachers also generally perceive themselves to have 'average' to 'poor' levels of information literacy including the technology skills and information

(C) 2010 IASL, SLAQ and therein by the authors. Diversity Challenge Resilience: School Libraries in Action Proceedings of the $12^{\text {th }}$ Biennial School Library Association of Queensland, the $39^{\text {th }}$ International Association of School Librarianship Annual Conference incorporating the $14^{\text {th }}$ International Forum on Research in School Librarianship, Brisbane QLD Australia, 27 September - 1 October 2010 . 
retrieval skills in the self-report study. This brings to light that there is a need for further training and support, although a detailed study of their actual skills needs to be carried out first. For that reason, this research attempts to unearth the facts and realities of the library media teachers' information literacy vagueness in Malaysia (Tan \& Diljit, 2008).

Other reasons due to the progress and innovation of information technologies, traditional physical part of school libraries have developed into virtual online libraries with automation systems, digital systems, online facilities and the integration of these into the services (Tan \& Diljit, 2008; McCoy, 2001), point out that those library media teachers' current job competencies are no longer confined to providing access to all types of materials. They have moved beyond the uses of electronic searches and search strategies. Serving as information specialists for teachers, they develop plans for technology integration, assist with multimedia approaches to instruction, and assist with the use of presentation software.

Library media teachers need to change if they are going to survive (Combes, 2008). Thus, they need to embrace, exploit, acquire and grasp the information skills and explore new technologies. They must keep pace with the changing times. They risk becoming dinosaur specimens if they do not catch up with these information transformation trends and understand the information skills (Herring, 2005; Tan \& Diljit, 2008). Many library media teachers do not recognize most of the technological competencies as essential. Nevertheless, the researcher feels that it is essential for all library media teachers to possess technological competencies such as having the skills to select, evaluate, and use microcomputer software. However, Siitonen (1996) deemed that information literacy goes beyond computer literacy and the use of computer produced information.

Accordingly, this research aims to examine the important issues related to the information literacy competencies among library media teachers in secondary schools in Malaysia. It also aims to find out what library media teachers think of information literacy in their responsibilities as information specialists. The research aims to identify definite reasons why library media teachers are in need of information literacy competencies. It hopes to act as a wake-up call for the stakeholders especially the Education Ministry to realize that Malaysian library media teachers are gravely in need of information literacy knowledge and expertise to perform on par as an information specialist with their international colleagues.

\section{Research questions}

This study aims to answer the following questions in relation to the stated objectives:

a. What are the perceptions of library media teachers in secondary schools towards information literacy?

b. What are the current levels of information literacy competencies among library media teachers in secondary schools?

c. What are the factors affecting the implementation of information literacy among library media teachers in secondary schools?

\section{Significance}

This research aims to examine important issues related to the information literacy competencies among library media teachers in secondary schools in Malaysia. This research will provide an insight into the current status of information literacy among library media teachers. This will be the baseline information for further studies and should contribute to the scholarly literature in library and information science in Malaysia. A literature review found that no studies have been done to investigate this subject, thus this research is the first in Malaysia.

The rationale for the study is to find out the needs of information literacy skills of library media teachers in the Malaysian education system. They, the information agents are to lead and extend the information literacy skills and knowledge to their clients; students, teachers and the administrative staff in schools. In order to be able to inculcate information skills to them, the library media teachers themselves must be knowledgeable and information literate (Gbaje, 2008; Novo \& Calixto, 2009; Scheirer, 2000; Tan \& Diljit, 2008).

(C) 2010 IASL, SLAQ and therein by the authors. Diversity Challenge Resilience: School Libraries in Action Proceedings of the $12^{\text {th }}$ Biennial School Library Association of Queensland, the $39^{\text {th }}$ International Association of School Librarianship Annual Conference incorporating the $14^{\text {th }}$ International Forum on Research in School Librarianship, Brisbane QLD Australia, 27 September - 1 October 2010. 
Moreover, library media teachers have gone through the primary, secondary, and tertiary education system and later they are professionally trained in education. They have also gone through intensive information and communication technology education in either their school education or professional training. Despite all these, information literacy skills are rather new for them. Learning information skills, computer literacy as well as communication skills is rather different. Being computer-literate does not mean being information literate. Being able to use the computers is not good enough. They must be able to identify information problems and be able to locate, use, synthesize, and evaluate information in relation to those problems (Drucker, 1992 cited in Eisenberg, 2008; Campbell, 2009).

There is countless research on qualities of teaching information literacy skills (Grafstein, 2002; Intan Azura, Majid, \& Foo, 2008a, 2008b). Most studies focus on developed countries and there are very few attempts to carry out information literacy research on the situations in developing country. There is a lack of research on what librarians, library media teachers, and subject teachers are doing to make information literacy skills an intrinsic feature of modern day school curriculum in these countries. This is a gap in the literature that needs to be filled (Jorosi \& Isaac, 2006).

There are information literacy papers written on these subject matters in the Malay language in local educational journals by Che Normadiah (2001), Faisal and Nor Azian (2006) and Norhayati (2006). Nevertheless, there are no local databases to cater for local scholarly papers in the Malay language systematically. Thus, many papers are not available in databases nor online searches. One has to manually search for them or write to the authors to gain access to the specific paper. Therefore, the local researches are largely unknown to the international scholarly researchers in this field.

Further research explores on Norhayati's (2009) designing and developing information literacy training module based on the Big Six skills for library media teachers. This qualitative research focuses on a small selected group of 20 library media teachers in Penang. It aims to provide information literacy training and the use of information skills. Therefore, research on assessment of library media teachers' information literacy is not found. There has not been any studies done to investigate this subject, thus this research is the first in Malaysia.

This research is an important contribution to the scholarly literature regarding the information literacy among library media teachers in Malaysia. This is the first research, which describes the current and existing development of information literacy among library media teachers in the country. It is hoped that the statistical data and result would be able to provide recommendations to the relevant divisions in the Ministry of Education to further improve and upgrade the training of library media teachers as a whole.

This research hopes to provide baseline information on the need of a well-designed information literacy policy and guidelines for information literacy in schools for library media teachers and students. These include the need of well designed standardized information literacy curriculum, syllabuses, modules and training for library media teachers. Thus, it also provides a baseline data for future studies in the area of information literacy of library media teachers. As a final point, there is a need for more extensive research to explore the progress of information literacy development in the Malaysian education system to create lifelong learning here.

\section{Scope of the study}

This research covered a sample of 36 library media teachers from the state of Selangor, Negeri Sembilan and Federal Territory of Kuala Lumpur. These three states comprise both rural and urban areas. For the purpose of this research, convenient samplings were used to obtain information from precisely 36 library media teachers who participated in the study.

(C) 2010 IASL, SLAQ and therein by the authors. Diversity Challenge Resilience: School Libraries in Action Proceedings of the $12^{\text {th }}$ Biennial School Library Association of Queensland, the $39^{\text {th }}$ International Association of School Librarianship Annual Conference incorporating the $14^{\text {th }}$ International Forum on Research in School Librarianship, Brisbane QLD Australia, 27 September - 1 October 2010. 
The study also focused on the perceptions of library media teachers about information literacy, selfassessment of information literacy competencies and the factors affecting the implementation of information literacy.

\section{Limitations of the study}

This study was based on self-reporting by library media teachers. The findings were based on the analysis of the questionnaires. Thus, the result of the research should be explained and interpreted appropriately.

\section{Literature review}

A thorough review of literature revealed an abundance of research about principals' perceptions of library media teachers and their instructional roles (Hartzell, 2002; Drake, 2007; Church, 2007, 2008), the changing role of library media teachers (McCracken, 2000; McCracken, 2001; Shelton, 2002), and collaboration (Pace, 2007; Montiel-Overall, 2009). Miller (2005), commented that there is a lack of literature investigating library media teachers' perceptions toward information literacy in schools.

For this reason, Miller (2005), took on an attempt to explore the perceptions of novice teachers regarding the role of the library media teacher in secondary schools through her qualitative study. Her study investigated whether novice teachers were aware of the role of library media teacher in implementing information literacy skills across the curriculum. She also looked into how accurate were their perceptions as well as if they were aware of the concept of information literacy. This study took place in a town in Western Canada, with thirtyseven elementary schools and seven secondary schools. She interviewed library media teachers. The results showed that there was a lack of understanding of teachers and administrators about the role of library media teacher in school secondary schools. All five of them unanimously agreed that they had never heard the term "information literacy", neither during their pre-service training nor during subsequent teaching experience. Since these new teachers were unfamiliar with the term "information literacy", none of them felt they had been specifically prepared to implement it in their classrooms. There is a big gap between teachers' perceptions of the role of the library media teacher, and the reality of the job and the initiative that is going to have to come from the library media teacher. The result indicated that further investigation in this scope will fill the gap.

Library media teacher are skilled in information literacy, knowledge of resources and pedagogy. They offer invaluable support and provide teachers with professional development. Their knowledge and expertise in this process enables the sharing of teaching of specific lessons. They have the responsibility to ensure that the teaching and learning process is taught as a comprehensive process, systematically and developmentally, to all students in the school (Eisenberg, 2003; Moore \& Trebilcock, 2003; Spence, 2005). Spence (2005) further argued that with these plus points, the school library and its staff are significant school assets, and need to be considered as an educational investment rather than a cost. Their combination of expertise in information literacy skills and knowledge of resources and pedagogy are able to offer invaluable support to hard-pressed teachers and principals. Thus, library media teachers should be regarded as potential assets rather than underutilized assets.

Students see the electronic media as their prime source of knowledge required for schoolwork and for their own edification. Nauman and Shaw (2007), highlighted that a practical solution would be to educate library media teachers in information literacy instructions to help elementary students become better consumers and users of correct information, both written and via the Internet. Generally, students possess the skill to define the need for information and to use the information once the resources are found. However, they face problems on how to locate and select sources of information due to the lack of knowledge on basic library skills and they do not know how to choose accurate information from the resources found. They lack the skills in using indexing as their tool to retrieve information and to choose relevant information and they have low information literacy level among them. There are also no programmes conducted at resource centres because of the time constraints and the lack of training regarding information literacy skills itself for students (Che Normadiah, 2001; Nor Hashimah, 2007; Raja Abdullah \& Saidina Omar, 2003)

(C) 2010 IASL, SLAQ and therein by the authors. Diversity Challenge Resilience: School Libraries in Action Proceedings of the $12^{\text {th }}$ Biennial School Library Association of Queensland, the $39^{\text {th }}$ International Association of School Librarianship Annual Conference incorporating the $14^{\text {th }}$ International Forum on Research in School Librarianship, Brisbane QLD Australia, 27 September - 1 October 2010 . 
On the other hand, Probert (2009) strongly argued that school students' lack information literacy skills, including working with online resources. Many students simply "copied and pasted" but no teachers indicated that students might need more strategies to help them develop better information skills. From her point of view, there is little research to investigate teachers' knowledge of information literacy skills and their related pedagogical practice. She also warned of the urgent need to provide information literacy professional development for teachers to train and prepare them to have the necessary skills of information literacy before teachers can guide students to master this important skill. They need the readiness, availability, and skills in providing instruction, answering questions, and encouraging inquiry to promote the development of information literacy skills. Thus, technology, teaching, collaboration, and leadership have become more prominent to address this comprehensive set of competencies which will benefit them (Shannon, 2001; Sakr, Nabhani, \& Osta, 2009). Nevertheless, the personal competencies are the important and fundamental factor and what might impact student's educational attainment (Novo \& Calixto, 2009).

In fact, Branch and De Groot (2009) stressed that library media teachers are taking on a leadership role in schools and need to provide opportunities for library media teachers to explore, discuss and reflect on change, school reform, assessment, advocacy, action research, and evidence-based practice. However, the role of the library media teachers in the 21st century is evolving quickly and even a Master of Education degree is not enough to keep up with the changing demands of the job. As a result, there is a need for formal and informal continuing education opportunities, which sadly is unclear for these teachers. As leaders in schools, library media teachers need to model lifelong learning and should try to seek out personal professional development that complements and expands on their education.

For the time being, the Malaysian Government spends billions of ringgits to develop quality human capital for the nation. The government continues to implement various programmes towards creation of a pool of trained and competitive work force (Ministry of Finance Malaysia, 2009). The government allocated RM 30 billion for primary and secondary education, which will benefit 5.5 million students nationwide. (Ministry of Finance Malaysia, 2010). All the allocations were for education, training, and infrastructure maintenance. Despite all this allocation, unfortunately there has been no serious planning or agenda for a national information literacy policy.

Consequently, information literacy in the country is moving aimlessly without any national agenda. There is a need to formulate a National Information Literacy Agenda or NILA, which could be used to plan, implement, and evaluate information literacy programmes. NILA will be able to provide a framework that will include the principles, standards and practices that will support information literacy education in all sectors. All parties or stakeholders who are directly or indirectly involved with any form of information literacy initiatives at any level must come together and establish NILA and a task group must be formed to implement this (Edzan, 2008; Edzan \& Mohd Sharif, 2005). Therefore, this research provides baseline information to enable and to persuade various divisions in the Ministry of Education to come forward and work with various academic counterparts in the country to work constructively for a strategic plan for our very own Malaysian National Information Literacy Agenda or MNILA.

The Education Technology Division in the state, district and zone levels have conducted information literacy professional development training programmes for these library media teachers but there is no serious effort to implement information literacy in the Malaysian education system. There is a lack of coordination within the divisions in the ministry itself as to which division should take the lead in implementing information literacy and providing the official guidelines on who, what, when, where and how to implement the information literacy skills as found by Norhayati (2009). The integration of information literacy into the ongoing reformation of the educational system needs to be undertaken in the context of these ongoing education policy formulation and reforms (Horton, 2008). Furthermore, to help bridge the gap between the policy and practice, teachers and library media teachers need to reflect on the changes to the educational culture associated with promoting lifelong learning (Bruce, 2002).

(C) 2010 IASL, SLAQ and therein by the authors. Diversity Challenge Resilience: School Libraries in Action Proceedings of the $12^{\text {th }}$ Biennial School Library Association of Queensland, the $39^{\text {th }}$ International Association of School Librarianship Annual Conference incorporating the $14^{\text {th }}$ International Forum on Research in School Librarianship, Brisbane QLD Australia, 27 September - 1 October 2010 . 
Papers by Chan (2002), Educational Technology Division (2005), Musa (2002), and Yusoff (2006) do provide substantiated evidence that information literacy is integrated into the curriculum. However there is no evidence of official information literacy policy statements in the national education policy except in the educational teaching module syllabuses (Bahagian Teknologi Pendidikan, 2002a) and information literacy syllabus specifications (Bahagian Teknologi Pendidikan, 2002b) found in school libraries. These modules are to help library media teachers in primary schools to teach information literacy to facilitate the usage of school libraries. On the other hand, from the literature search, there is no clear implementation of information literacy policy or guidelines. Furthermore, the emphasis on information, communication, and technology resulted in information literacy being forgotten (Che Normadiah, 2001; Norhayati, 2009).

Therefore, this research is timely to understand and identify the library media teachers' information literacy competencies to perform as information specialists in school resource centres.

\section{Methodology}

This research employed a descriptive research design. It illustrated the characteristics of an existing phenomenon at the current time (Salkind, 2006) which provided a broad picture of the current information literacy competencies among library media teachers in secondary schools. This research used a quantitative approach which utilized the survey method to generate a diverse range of responses from the random samples of library media teachers in secondary schools (Pole \& Lampard, 2002).

\section{Populations samplings}

The populations of this research are the secondary library media teachers. This is a preliminary research using convenience sampling technique. Precisely, 36 library media teachers participated in the study. They were from the state of Selangor, Negeri Sembilan and Kuala Lumpur. From the state of Selangor, 28 of them were from Hulu Langat and one from Petaling Jaya. From Federal Territory of Kuala Lumpur, there were four from Cheras, one from Bangsar, and one from Petaling. From the state of Negeri Sembilan, there was one from Jelebu. From the total of 36 library teachers, $52.8 \%$ were from the urban area while the balance of $47.2 \%$ were from the rural areas.

\section{Data collections}

The study was undertaken as a needs assessment survey to solicit library media teachers' opinion about information literacy problems and possible solutions (Salant \& Dillman, 1994) pp. 10. The questionnaires were sent out to the Teachers' Activities Centre as well as by emails. These questionnaire were selfadministered and the teachers were able to understand the questionnaires correctly (Redline, Dillman, \& Carley-Baxter, 2005).

\section{Instrumentation}

This study was the pilot test of an ongoing research by the researcher. It was carried out in the duration of four weeks. The questionnaire was tested for validity and reliability to establish the suitability and appropriateness of the instruments. These were to ensure that the instruments were appropriate, accurate, correct, credible, meaningful, and useful for the research as a whole. Next, the researcher submitted the instruments to her supervisor for further review. All comments and evaluations were noted and rectified.

Subsequently, the questionnaires were validated by renowned information literacy and library media teachers' experts, namely Prof. Dr. Lesley Farmer of California State University Long Beach, Dr. Megan Oakleaf of Syracuse University and Dr. Penny Beile of University Central Florida, United States. Their reviews, feedback, and comments were noted. The researcher amended and improved the instruments as needed.

The questionnaire consisted of sixty-three questions in four sections. They were the demographic information, the perceptions of library media teachers about information literacy, self-assessment of information literacy competencies and the factors affecting the implementation of information literacy.

() 2010 IASL, SLAQ and therein by the authors. Diversity Challenge Resilience: School Libraries in Action Proceedings of the $12^{\text {th }}$ Biennial School Library Association of Queensland, the $39^{\text {th }}$ International Association of School Librarianship Annual Conference incorporating the $14^{\text {th }}$ International Forum on Research in School Librarianship, Brisbane QLD Australia, 27 September - 1 October 2010. 
The first section contained six items. There were demographic questions designed to assess the characteristics of the participants such as the location of their schools, in which states, in rural or urban area, the infrastructure facilities in their schools, their teaching experience, their experience being library media teachers, any School Resource Management courses attended as well as their Library and Information Science qualifications.

The second section comprised nineteen items that include the library media teachers' various opinions and perceptions towards the concept and understanding of information literacy. The respondents were asked to indicate the extent of their agreement with a list of information literacy statements using a five-item Likert scale ranging from 1 for "Strongly disagree" to 5 "for Strongly agree".

\section{Example 1:}

Section II. Perceptions of Library Media Teachers about Information Literacy.

To what extent do you agree or disagree with these elements of information literacy? Please tick $(\sqrt{ })$ the number that best describes the extent of your opinion, ranging from 1 for Strongly disagree to 5 for Strongly agree.

$\begin{array}{ll}\text { Strongly disagree } & =1 \\ \text { Somewhat disagree } & =2 \\ \text { Neutral } & =3 \\ \text { Somewhat agree } & =4 \\ \text { Strongly agree } & =5\end{array}$

\begin{tabular}{|c|c|c|c|c|c|c|}
\hline 7. & $\begin{array}{l}\text { Information literacy enables you to access, evaluate, and use information from a } \\
\text { variety of sources. }\end{array}$ & 1 & 2 & 3 & 4 & 5 \\
\hline 8. & Information literacy is a set of skills that can be learned. & 1 & 2 & 3 & 4 & 5 \\
\hline
\end{tabular}

The third section comprised fourteen statements on information literacy competencies. Respondents were requested to indicate their self-estimated information literacy abilities based on a five-item Likert scale ranging from 1 for "Do not know at all" to 5 for "Excellent". These statements were adopted and adapted from the Information Literacy Big Six Model.

\section{Example 2:}

Section III. Self-Assessment of Information Literacy Competencies.

Please indicate your level of your information literacy abilities of the following skills. Please tick $(\sqrt{ })$ the number that best describe your abilities, ranging from 1 for Do not know at all to 5 for Excellent.

$\begin{array}{ll}\text { Do not know at all } & =1 \\ \text { Poor } & =2 \\ \text { Average } & =3 \\ \text { Good } & =4 \\ \text { Excellent } & =5\end{array}$

\begin{tabular}{|l|l|l|l|l|l|l|}
\hline 27. & Identify information needed (to solve the information problem). & 1 & 2 & 3 & 4 & 5 \\
\hline 29. & Select the best sources of information. & 1 & 2 & 3 & 4 & 5 \\
\hline
\end{tabular}

The fourth section of the research instrument comprised twenty-two items on the factors affecting the implementation of information literacy in schools. The respondents were requested to indicate the degrees of importance that these aspects have on the implementation of information literacy in schools. All these answers were in a five-item Likert scale ranging from 1 for "Not important at all" to 5 for "Extremely important". The final two questions were to solicit opinions or further comments regarding the research. 


\section{Example 3:}

IV. Factors Affecting Implementation of Information Literacy. Please tick the applicable number.

To what degree of importance are these aspects needed for the implementation of information literacy in schools? Please tick $(\sqrt{ })$ the number that best describe your opinion on the importance of the factors, ranging from 1 for Not important at all to 5 for Extremely important

$\begin{array}{ll}\text { Not important at all } & =1 \\ \text { Somewhat not important } & =2 \\ \text { No opinion either way } & =3 \\ \text { Somewhat important } & =4 \\ \text { Extremely important } & =5\end{array}$

\begin{tabular}{|c|c|c|c|c|c|c|}
\hline & Implementation & & & & & \\
\hline 41. & Library media teachers need information literacy professional development. & 1 & 2 & 3 & 4 & 5 \\
\hline & Policies & & & & & \\
\hline 52. & $\begin{array}{l}\text { An information literacy education guideline for library media teachers is } \\
\text { needed. }\end{array}$ & 1 & 2 & 3 & 4 & 5 \\
\hline
\end{tabular}

\section{Results}

The data was statistically analyzed using the SPSS software. All the items were analyzed using descriptive analysis. Reliability test and validation were taken into considerations.

The 56 questions on the teachers' perception on information literacy, their information literacy competencies and the factors affecting the implementation of information literacy in curriculum resulted in Cronbach's Alpha reliability of 0.961 indicating that the measurement reflected high reliability (Gay, Mills, \& Airasian, 2009; Radhakhrishna, 2007; Vogt, 2007). The item mean was 4.012 which reflected that a high number of respondents agreed to the statements. Following these results, findings from a selected number of questions are discussed in this paper.

\section{Background questions}

In terms of facilities, most of these schools have electricity facility and $97.2 \%$ of the schools have computer and internet facilities.

In terms of library qualifications, $30.6 \%$ of them were without any school resource centre management training while $38.9 \%$ of them had attended the Basic Resource Centre Management 35 hours Course. Only $13.9 \%$ of them had attended the Advance Resource Centre Management 45 hours Course. Another 5.6\% had attended the 14 weeks In-Service Resource Centre Management Course. 2.8\% of them had Bachelors Degree in Library and Information Science / Educational Technology and 8.3\% had a Masters in Library and Information Science / Educational Technology. The mean score for Resource Centre Management qualification is 1.58 , which is low and reflects that the teachers are therefore in need of proper training in library and information science.

All the library media teachers are teachers by profession. The library media teachers' teaching experiences range from 0.2 months to 22 years, with the mean of 10.52 years that showed that the library media teachers are experienced teachers. However, their experiences as library media teachers range from 0 to 15 years, with a mean of 3.04 years. Therefore, the results showed that the library media teachers' library management experience is relatively new. This is a lower mean when compared to an earlier research that gave a mean of 4.1 years (Tan \& Diljit, 2008).

\section{Perceptions of the library media teachers}

Table 1 contains the results from five selected questions examining library media teachers' perception of information literacy. The high mean of 4.22 reflected a high number of library media teachers somewhat agreeing to the statement that information literacy enables them to access, evaluate, and use information. The

(C) 2010 IASL, SLAQ and therein by the authors. Diversity Challenge Resilience: School Libraries in Action Proceedings of the $12^{\text {th }}$ Biennial School Library Association of Queensland, the $39^{\text {th }}$ International Association of School Librarianship Annual Conference incorporating the $14^{\text {th }}$ International Forum on Research in School Librarianship, Brisbane QLD Australia, 27 September - 1 October 2010. 
mean of 4.33 showed that these library media teachers somewhat agreed that information literacy is a set of skills that can be learned. They also somewhat agreed that library media teachers should perform as information specialists in schools as indicated by a mean of 4.25 .

Table 1. Perceptions on information literacy $(n=36)$.

\begin{tabular}{|l|l|}
\hline Perceptions & Mean \\
\hline Information literacy enables you to access, evaluate, and use information. & 4.42 \\
\hline Information literacy is a set of skills that can be learned. & 4.33 \\
\hline The information literate person integrates information found to the existing knowledge. & 4.28 \\
\hline Library media teachers should perform as information specialists. & 4.25 \\
\hline The information literate person recognizes the need for information. & 4.22 \\
\hline
\end{tabular}

Table 2 illustrates the distribution of the library media teachers' perceived self-estimated information skills. An analysis of the mean scores for each of the 5 skills showed that most of the respondents rated their information literacy skills between average and good. The skill to identify information needed scored the highest mean of 3.94. The skill to synthesize information found in the source scored the lowest mean of 3.47. The results indicated that the current level of information literacy competencies among the library media teachers are between average to good. The results pointed out that library media teachers are indeed in need of more exposure to and training in information literacy skills. The high number of the library media teachers who do not have any basic training in school resource centre management is also one of the main reasons for the low mean.

Table 2. Mean scores for information literacy skills $(\mathbf{n}=36)$.

\begin{tabular}{|l|l|}
\hline Self-assessment information literacy skills. & Mean \\
\hline Identify information needed (to solve the information problem). & 3.94 \\
\hline Select the best sources of information. & 3.83 \\
\hline Determine all possible sources of information. & 3.72 \\
\hline Find information within sources. & 3.5 \\
\hline Synthesize information found in the source. & 3.47 \\
\hline
\end{tabular}

\section{Factors affecting the implementation of information literacy in schools.}

The research was to identify the factors affecting the implementation of information literacy among library media teachers in secondary schools. The literature reviews summarized 5 main factors which include the implementations of information literacy, policies, standards, education for library media teachers and finally the infrastructures.

Aspects needed to implement information literacy.

The results in table 3 pointed out the aspects needed to implement information literacy in schools. The mean score of 4.44 indicated that most of the library media teachers' felt that information literacy professional development should be provided for them. The result also pointed out that they are in need of professional development as well as information literacy courses in their career. The high mean of 4.22 underlined that library media teachers do indeed need to gain knowledge of information literacy instruction (pedagogy) on how to teach students. Overall, the results pointed toward the need to implement information literacy in the education curriculum. 
Table 3: Implementation of information literacy $(n=36)$.

\begin{tabular}{|l|l|}
\hline Implementation & Mean \\
\hline Information literacy professional development should be provided for library media teachers. & 4.44 \\
\hline Library media teachers need information literacy professional development. & 4.31 \\
\hline The library media teacher needs to take information literacy courses. & 4.22 \\
\hline $\begin{array}{l}\text { Library media teachers need to learn information literacy instruction (pedagogy) on how to teach } \\
\text { students. }\end{array}$ & 4.22 \\
\hline Need to implement information literacy in the education curriculum. & 4.14 \\
\hline
\end{tabular}

From the Table 4 below, it can be seen that the respondents somewhat agreed that information literacy education guideline is important to implement information literacy in schools with the mean of 4.06. The mean of 3.94 implied that an information literacy education policy for library media teachers is also needed. However, the need of a national information literacy agenda is much lower with the mean of 3.92. This signified that the teachers are in need of precise practical implementation that suits the schools environment. The results of these teachers' opinions also showed that applicable policies are needed for library media teachers if the Ministry of Education is seriously considering implementing information literacy.

Table 4: Policies for the implementation of information literacy $(n=36)$..

\begin{tabular}{|l|l|}
\hline Policies & Mean \\
\hline An information literacy education guideline for library media teachers is needed. & 4.06 \\
\hline An information literacy education policy for library media teachers is needed. & 3.94 \\
\hline A national information literacy agenda is needed. & 3.92 \\
\hline
\end{tabular}

Table 5 shows that the participants did not agree unanimously that there is a need for standards for the implementation of information literacy. The mean of 3.95 suggested that a slightly higher number of teachers selected the 'no opinion either way' or 'somewhat important' option. The statement that an information literacy standard for students is needed, obtained a 3.89 mean. However, the implementation of information literacy excluding standards is a sign of aimless strategy without any indicator in implementing policies.

Table 5: Standards for the implementation of information literacy $(n=36)$.

\begin{tabular}{|l|l|}
\hline Standards & Mean \\
\hline National information literacy standard is needed. & 3.92 \\
\hline Information literacy standard for students is needed. & 3.89 \\
\hline
\end{tabular}

The results from table 6 showed that the library media teachers felt that the need for continuing education opportunities in Library and Information Science are somewhat important with the mean of 4.33. They also felt that a standardized training curriculum, standardized information literacy training modules, and information literacy training are important in order to train skilful and knowledgeable teachers with the mean above 4.17. It also indicated that the library media teachers felt that it is somewhat important to have Library and Information Science certification for their professions with the mean of 4.03. This is a positive indication that it is time for the Ministry of Education to design and offer a better qualification credential for these teachers. 
Table 6: Education for the implementation of information literacy $(n=36)$.

\begin{tabular}{|l|l|}
\hline Library Media Teachers' Education & Mean \\
\hline $\begin{array}{l}\text { Library media teachers need continuing education opportunities in Library and Information } \\
\text { Science. }\end{array}$ & 4.33 \\
\hline Library media teachers need a standardized information literacy training curriculum. & 4.31 \\
\hline Library media teachers need standardized information literacy training modules. & 4.31 \\
\hline Library media teachers need information literacy training. & 4.17 \\
\hline Library media teachers need Library and Information Science certification. & 4.03 \\
\hline
\end{tabular}

The infrastructure facilities are shown in table 7. Both aspects scored a mean of 4.44 . The results indicated that information technology facilities in schools are important in order to make it possible for school libraries to function as information centres. Infrastructure facilities determine and influence the set ups of information literacy environment in schools.

Table 7: Infrastructure for the implementation of information literacy $(n=36)$.

\begin{tabular}{|l|l|}
\hline Infrastructure & Mean \\
\hline Information technology facilities in schools & 4.44 \\
\hline School libraries function as information centres & 4.44 \\
\hline
\end{tabular}

\section{Discussions}

Although the literature search indicated that teachers lack understanding of the concept of information literacy, the results here indicated that respondents perceive information literacy as much needed skills for their professions. Miller (2005)'s research indicated similar results that new teachers are unfamiliar with the term information literacy. However, the results pointed out that these teachers are experienced teachers but they are new library media teachers. This research filled the gap of the library media teachers' perceptions towards information literacy but not their perceptions towards the role of the library media teachers, nor the reality of the job. The result established that the teachers recognize library media teachers as information specialists with their expertise in information literacy, resources, and pedagogy. This indicated that library media teachers are highly regarded as potential assets in schools rather than underutilized assets.

The results from this self-assessment verified the worries over the level of library media teachers' knowledge of information literacy skills and their related pedagogical practice. This also confirmed that indeed the library media teachers need information literacy professional development as well as training in order to guide the students to use the same skills. Conclusively, the respondents viewed that information professional development should be provided to library media teachers and they needed information literacy. They also felt that they needed to attend information literacy courses to enhance the information literacy instruction (pedagogy) knowledge and it is important to implement information literacy in the education curriculum. Therefore, library media teachers certainly need clear formal and informal continuing education opportunities for their career advancement to promote further passion in teacher librarianship.

In some ways, the respondents indicated that it is important to have proper policies, guidelines and a national agenda in order to implement information literacy successfully. Due to the cultural work style of the organizations and administrations in the country, the information literacy implementation need to be driven from top-down. Thus, the position of a national policy, guidelines, and a national agenda would definitely facilitate a successful implementation of information literacy in the country. Therefore, it needs long term strategic planning in order to achieve an effective and irrevocable result. 


\section{Conclusion}

Generally, library media teachers need to further improve their information literacy skills and have confidence in their knowledge and acquired information skills. They perceived that they needed information literacy and it is important in their line of work. Additional continuing education opportunities, professional development, and training in information literacy will enhance the expertise of these teachers as information specialists in schools.

Apart from policies and strategic planning, schools' infrastructures influence the information literacy environment. A well-equipped information technology infrastructure in schools will evolve school libraries into information centres. However, all these will go on the blink without a well-structured national information agenda, policy, and guidelines to lay down concrete foundations to the implementation of information literacy. Significant information literacy framework has to be developed and compulsory information literacy programmes need to be put into practice to benefit library media teachers and students as well as to foster information literate generation and society. This calls for information specialist leaders, stakeholders, and the government to lead the way to form an information literacy strategy.

\section{Three key learnings:}

- The information literacy competencies of current library media teachers need to be improved.

- There is a need to standardize the training of library media teachers in relation to information literacy

- There is a need for a strategic plan to implement information literacy in Malaysian schools.

\section{Acknowledgements}

We would like to express our gratitude to all the library media teachers and education technology officers for their support and assistance in carrying out this study. We also sincerely thank all teachers who responded to the survey.

\section{References}

Abrizah, A. (1999). Competencies for teacher librarians in Malaysia. Malaysian Journal of Library \& Information Science, 4 (2), 21-40.

Abrizah A. (2008). Building an information literate school community: approaches to inculcate information literacy in secondary school students. Journal of Information Literacy, 2(2), 15.

Bahagian Teknologi Pendidikan. (2002a). Modul pengajaran dan pembelajaran penggunaan pusat sumber sekolah dan kemahiran maklumat. Kuala Lumpur: Bahagian Teknologi Pendidikan, Kementerian Pendidikan Malaysia.

Bahagian Teknologi Pendidikan. (2002b). Modul pengajaran dan pembelajaran penggunaan pusat sumber sekolah dan kemahiran: Sukatan dan huraian Tahun 1 hingga Tahun 6. Kuala Lumpur: Kementerian Pendidikan Malaysia.

Boekhorst, A. K. (2003). Becoming information literate in the Netherlands. Library Review, 52(7), 298-309.

Boelens, H. (2006). A new kind of information specialist for a new kind of learning. Paper presented at the World Library and Information Congress: 72nd IFLA General Conference and Council 20-24 August 2006. Retrieved June 9, 2008, from http://www.ifla.org/IV/ifla72/index.htm.

Branch, J. L., \& De Groot, J. (2009). The Future in Focus: Preparing Teacher-Librarians for the 21st Century Paper presented at the Proceedings of the 13th International Forum on Research in School Librarianship, the 38th Annual Conference and the International Association of School Librarianship International Federation of Library Associations and Institutions Joint Meeting, Abano Terme, Padova, Italy: International Association of School Librarianship. 
Bruce, C. S. (2002). Information Literacy as a Catalyst for Educational Change: A Background Paper, July 2002, White Paper prepared for UNESCO, the U.S. National Commission on Libraries and Information Science, and the National Forum on Information Literacy, for use at the Information Literacy Meeting of Experts, Prague, The Czech Republic. Retrieved August 12, 2009, from

http://www.nclis.gov/libinter/infolitconf\&meet/papers/bruce-fullpaper.pdf

Campbell, P. (2009). Why Would Anyone Want to Follow the Leader? School Library Media Activities Monthly, 2 (8), 52.

Campello, B. (2009). Developing Students' Information Skills in Brazilian School Libraries: The Librarian's Role. School Libraries Worldwide, 15 (1), 14-27.

Carr, J. A. (1998). Information literacy and teacher education. ERIC Digest, ERIC Clearinghouse on Teaching and Teacher Education Washington DC. Retrieved August 14, 2009, from http://www.ericdigests.org/1999-2/information.htm

Catts, R., \& Lau, J. (2008). Towards information literacy indicators: Conceptual framework paper. Paris: UNESCO.

Chan, F. M. (2002). Developing information literacy in Malaysian Smart Schools: resource-based learning as a tool to prepare today's students for tomorrow's society. Paper presented at the School Libraries for a Knowledge Society: Proceedings of the 31st Annual Conference of the International Association of School Librarianship and the 6th International Forum on Research in School Librarianship, 5-9 August, Petaling Jaya, Malaysia.

Che Normadiah Che Abbas. (2001). Pusat Sumber Sekolah sebagai penyokong kemahiran maklumat: Pengenalan dan Konsep. Jurnal Bahagian Teknologi Pendidkan, Disember, 3, 42-47.

Church, A. P. (2007). Elementary school principals' perceptions of the instructional role of the school library media specialist. Unpublished Ph.D., Virginia Commonwealth University, United States -- Virginia.

Church, A. P. (2008). The Instructional Role of the Library Media Specialist as Perceived by Elementary School Principals. School Library Media Research, 11, 7-7.

Combes, B. (2005). Computers, ICTs and Online Curriculum: A Role for the Teacher Librarian? Paper presented at the Information Leadership in a Culture of Change: The 34th Annual Conference of the International Association of School Librarianship, and Ninth International Forum on Research in School Librarianship, 8-12 July 2005. Hong Kong, China.

Combes, B. (2008). Teacher librarianship in the twenty-first century. Paper presented at the Adapted from a keynote presentation at 7th Biennial ISASA School Librarians' Conference, Johannesburg, 8-10 August 2006. [Online]. Retrieved July 13, 2009, from www.alia.org.au/education/summit08/teacher.librarianship.pdf

Diao, A. L., \& Chandrawati, T. (2005). Current state of information literacy awareness and practices in primary and secondary public schools in Jakarta. Bangkok: Development of information literacy through school libraries in South-East Asian Countries. (IFAP Project 461RAS5027), UNESCO.

Drake, E. D. (2007). The role of the school library media specialist in Michigan: State-wide survey of practices and perceptions. Unpublished Ph.D., Michigan State University, United States -- Michigan.

Duke, T. S., \& Ward, J. D. (2009). Preparing information literate teachers: A metasynthesis. Library \& Information Science Research, In Press, Corrected Proof, Available online 30 June 2009.

(C) 2010 IASL, SLAQ and therein by the authors. Diversity Challenge Resilience: School Libraries in Action Proceedings of the $12^{\text {th }}$ Biennial School Library Association of Queensland, the $39^{\text {th }}$ International Association of School Librarianship Annual Conference incorporating the $14^{\text {th }}$ International Forum on Research in School Librarianship, Brisbane QLD Australia, 27 September - 1 October 2010. 
Educational Technology Division. (2005). Current state of information literacy practices in primary and secondary public schools in urban and rural areas: Ministry of Education, Malaysia.

Edzan, N. N. (2008). Information literacy development in Malaysia: A review. International Journal of Libraries and Information Services (Libri),58(4), 211-311.

Edzan, N. N., \& Mohd Sharif Mohd, S. (2005). NILA: a National Information Literacy Agenda for Malaysia. Malaysian Journal of Library \& Information Science, 10(1), 91-103.

Eisenberg, M. B. (2003). Implementing information skills: Lessons learned from the Big6 approach to information problem-solving. School Libraries in Canada, 22(4), 20.

Eisenberg, M. B. (2008). Information literacy: Essential skills for the information age. DESIDOC Journal of Library \& Information Technology, 28(2), 39-47.

Faisal Mohamad, \& Nor Azian Mohd Darus. (2006). Penggunaan modul pengajaran literasi maklumat di kalangan guru-guru sekolah projek semarak Pusat Sumber Sekolah di Pejabat Pendidikan Daerah Padang Terap, Pendang. Paper presented at the Seminar penyelidikan pendidikan: Pendidikan dalam literasi maklumat pemangkin pendidkan berkualiti 27-28 Jun 2006. Institut Perguruan Darulaman, Jitra, Kedah.

Gay, L. R., Mills, G. E., \& Airasian, P. (2009). Educational research: Competencies for analysis and applications (9th ed.). London: Pearson Education Ltd.

Gbaje, E. S. (2008). Basic Library Skills for Teacher Librarians. Paper presented at the Capacity Building Programme for Teacher Librarians Organized by Universal Basic Education Board Gusau Zamfara State 5th8th May, 2008.

Grafstein, A. (2002). A discipline-based approach to information literacy. The Journal of Academic Librarianship, 28(4), 197-204.

Hartzell, G. (2002). The principal's perceptions of school libraries and teacher-librarians. School Libraries Worldwide, 8(1), 92-110.

Henri, J. (2001). Thinking and informing: A reality-check on class teachers and teacher librarians. Inspiring connections: Learning, libraries and literacy. Paper presented at the Inspiring connections: Learning, libraries and literacy. Proceedings of the Fifth International Forum on Research in School Librarianship and the 30th annual conference of the International Association of School Librarianship, 9-12 July 2001, Auckland, New Zealand.

Herring, J. E. (2005). The end of the teacher-librarian. Teacher Librarian; ProQuest Education Journals, Oct, 33(1), 26.

Horton, F. W. J. (2008). UNESCO Information for All Programme "Understanding information literacy: A Primer". PARIS, UNESCO.

Horton, J. F. W. (2006). Information Literacy and Lifelong Learning Guidelines on information literacy for lifelong learning Boca del Río, Veracruz, México.: Information Literacy Section, IFLA.

Intan Azura Mokhtar, Shaheen Majid, \& Foo, S. (2008a). Information literacy education: Applications of mediated learning and multiple intelligences. Library \& Information Science Research, 30(3), 195-206.

Intan Azura Mokhtar, Shaheen Majid, \& Foo, S. (2008b). Teaching information literacy through learning styles: The application of Gardner's multiple intelligences. Journal of Librarianship and Information Science, 40(2), 93.

(C) 2010 IASL, SLAQ and therein by the authors. Diversity Challenge Resilience: School Libraries in Action Proceedings of the $12^{\text {th }}$ Biennial School Library Association of Queensland, the $39^{\text {th }}$ International Association of School Librarianship Annual Conference incorporating the $14^{\text {th }}$ International Forum on Research in School Librarianship, Brisbane QLD Australia, 27 September - 1 October 2010. 
Jorosi, B., \& Isaac, G. (2006). The teaching of information literacy skills in Botswana's Community Secondary Schools: A study of Gaborone region. Paper presented at the The Multiple Faces of Literacy: Reading, Knowing, Doing -- International Association of School Librarianship Reports, 2006: Selected Papers from the 35th annual conference of the International Association of School Librarianship, and the Tenth International Forum on Research in School Librarianship, 3-7 July 2006. Lisbon, Portugal.

Ketua Pengarah Pelajaran Malaysia (2005). Surat Pekeliling Ikhtisas BIL.3 /2005. Penyelarasan Waktu Mengajar bagi Guru Penyelaras Bestari serta Guru Perpustakaan dan Media Sekolah (Guru Penyelaras Pusat Sumber Sekolah). In: MALAYSIA, K. P. (ed.). Putrajaya, Malaysia: Kementerian Pelajaran Malaysia.

McCoy, B. S. (2001). A survey of practicing school library media specialists to determine the job competencies that they value most. Unpublished Ph.D., Georgia State University, United States -- Georgia.

McCracken, A. (2000). Perceptions of school library media specialists regarding their roles and practices. Unpublished Ph.D., George Mason University, United States -- Virginia.

McCracken, A. (2001). School library media specialists' perceptions of practice and importance of roles described in Information Power. School Library Media Research, 4 (2001), Retrieved August 4, 2009, from http://www.ala.org/ala/mgrps/divs/aasl/aaslpubsandjournals/slmrb/slmrcontents/volume42001/mccracken.cf $\mathrm{m}$

Miller, K. (2005). Novice Teachers' Perceptions of the Role of the Teacher-librarian in Information Literacy. School Libraries in Canada; The Profession of Teacher-Librarianship, 24(3), 13.

Ministry Of Finance Malaysia. (2009). Malaysians 2009 National Budget. Kuala Lumpur: Ministry Of Finance Malaysia.

Ministry Of Finance Malaysia. (2010). Malaysians 2010 National Budget. Kuala Lumpur: Ministry Of Finance Malaysia.

Montiel-Overall, P. (2009). Teachers' perceptions of teacher and librarian collaboration: Instrumentation development and validation. Library \& Information Science Research, September, 31(3), 82-191.

Moore, P., \& Trebilcock, M. (2003). The School Library Team: How Does It Influence Learning and Teaching? Paper presented at the School libraries: Breaking down barriers. Proceedings of the 32nd annual conference of the International Association of School Librarianship and the 7th International Forum on Research in School Librarianship, 7-11 July 2003. Durban, South Africa

Musa Mohamad. (2002). Official Opening Speech: Minister of Education Malaysia. Paper presented at the School libraries for a knowledge society: Proceedings of the 31st annual conference of the International Association of School Librarianship, and the Sixth International Forum on Research in School Librarianship, 5-9 August 2002. Petaling Jaya, Malaysia

Nauman, A. K., \& Shaw, E. L. J. (2007). Teacher education and information literacy: A course proposal Paper presented at the Cyberspace, D-world, E-learning: Giving Libraries and Schools the Cutting EdgeSelected paper from the 36th Annual International Association of School Librarianship Conference incorporating the 11th International Forum on Research in School Librarianship, 16-20 July 2007. Taipei, Taiwan.

Nor Hashimah Hussain. (2007). Information literacy among secondary school students at fully residential schools in Kuala Lumpur. University Malaya, Kuala Lumpur.

(C) 2010 IASL, SLAQ and therein by the authors. Diversity Challenge Resilience: School Libraries in Action Proceedings of the $12^{\text {th }}$ Biennial School Library Association of Queensland, the $39^{\text {th }}$ International Association of School Librarianship Annual Conference incorporating the $14^{\text {th }}$ International Forum on Research in School Librarianship, Brisbane QLD Australia, 27 September - 1 October 2010. 
Norhayati Razali. (2009). Reka bentuk dan pembangunan modul latihan kemahiran literasi maklumat berasaskan model The Big6. Universiti Sains Malaysia, Pulau Pinang.

Norhayati Razali, Nor Azilah Ngah, \& Mona Masood. (2006). Penilaian selepas latihan oleh guru-guru perpustakaan media selepas melalui modul latihan literasi maklumat berasaskan The Big6. Proceedings of the 19 th Malaysian Educational Technology Convention, 9-11 September 2006. Langkawi, Malaysia.

Novo, A., \& Calixto, J. A. (2009). Academic achievement and/or educational attainment - The role of teacher librarians in students' future: main findings of a research in Portugal. Paper presented at the Preparing pupils and students for the future: School libraries in the picture. Proceeding of the 13th International Forum on Research in School Librarianship, the 38th Annual Conference and the IASL-IFLA Joint Meeting. 2-4 September 2009. Padova, Italy

Pace, T. (2007). Perceptions of Florida school library media specialists relative to the saliency of collaboration, leadership, and technology tasks outlined in "Information Power": Changes since 1996. Unpublished Ph.D., University of South Florida, United States -- Florida.

Pinto, M., Cordón, J. A., \& Gómez Díaz, R. (2010). Thirty years of information literacy (1977—2007) : A terminological, conceptual and statistical analysis. Journal of Librarianship and Information Science, 42(1), 3-19.

Pole, C. J., \& Lampard, R. (2002). Practical Social Investigation: Qualitative and Quantitative Methods in Social Research. Essex: Pearson Education Limited.

Probert, E. (2009). Information literacy skills: Teacher understandings and practice. Computers \& Education, Aug., 53(1), 24-33.

Radhakhrishna, R. B. (2007). Tips for developing and testing questionnaires/instruments. Journal of Extention, Feb, 4 (1), 4.

Raja Abdullah Raja Yaacob, \& Saidina Omar Samsuri. (2003). The training of teacher librarian in comparison with professional librarians in Malaysia. Malaysian Journal of Library \& Information Science, $8(2), 27-41$.

Ranaweera, P. (2008). Importance of information literacy skills for an information literate society. Paper presented at the In Proceedings NACLIS 2008, Colombo, Sri Lanka

Redline, C. D., Dillman, A. D., \& Carley-Baxter, L. (2005). Factors that influence reading and comprehension in self-administer questionnaires. Allgemeines Statistisches Archiv, Feb, 89(1), 21-38.

Sakr, R., Nabhani, M., \& Osta, I. (2009). Description and evaluation of the information literacy program in a private school in Lebanon: A case study. School Libraries Worldwide, 15 (1), 28-44.

Salant, P., \& Dillman, A. D. (1994). How to conduct your own survey. New York: John Wiley \& Sons, Inc.

Salkind, N. J. (2006). Exploring research (Version 6th). New Jersey, United State of America: Pearson Education International.

Scheirer, B. (2000). The changing role of the teacher-librarian in the twenty-first century. University of Saskatchewan, Saskatchewan: Canada.

Shannon, D. (2001). The education and competencies of school library media specialists: A review of the literature. School Library Media Research, December, 5. Retrieved September 12, 2009, from http://www.ala.org/ala/mgrps/divs/aasl/aaslpubsandjournals/slmrb/slmrcontents/volume52002/shannon.cfm

(C) 2010 IASL, SLAQ and therein by the authors. Diversity Challenge Resilience: School Libraries in Action Proceedings of the $12^{\text {th }}$ Biennial School Library Association of Queensland, the $39^{\text {th }}$ International Association of School Librarianship Annual Conference incorporating the $14^{\text {th }}$ International Forum on Research in School Librarianship, Brisbane QLD Australia, 27 September - 1 October 2010. 
Shelton, P. W. (2002). Perception of the changing role of the library media specilaist. University of New Orleans, New Orleans.

Siitonen, L. (1996). Information Literacy: Gaps between concept and applications Paper presented at the 62nd IFLA General Conference - Conference Proceedings - August 25-31, 1996. Beijing, China.

Spence, S. (2005). Teacher librarians, an underutilized asset in schools. Curriculum Leadership, 3 (14)(14), Retrieved May 20, 2009, from

http://www.curriculum.edu.au/leader/teacher_librarians,_an_under_utilised_asset,9258.html?issueID=9776

Tan, S.-M., \& Singh, D. (2008). An Assessment of the information literacy levels of library and media teachers in the Hulu Langat district, Malaysia. Paper presented at the Towards an information literate society: International Conference on Libraries, Information and Society, ICoLIS 2008, 18-19 November 2008. Petaling Jaya, Malaysia

Tan, S.-M., \& Singh, D. (2008). Competencies for teacher-librarians: The Malaysians perspective; Kompetensi Guru Perpustakaan dan Media: Perspektif Malaysia. Paper presented at the Indonesian Convention and Seminar on School Librarian 27-29 May, 2009. Jakarta, Indonesia.

Vogt, P. W. (2007). Quantitative research methods for professionals. Boston: Allyn and Bacon.

Yusoff Harun. (2006). The development and implementation of information literacy in Malaysian school setting. Paper presented at the Information Literacy and Knowledge Society: Development, Changes and Challenges. Proceedings of the International Conference on Information Literacy, 1-15 June 2006. Kuala Lumpur, Malaysia.

\section{Statement of Originality}

This statement certifies that the paper above is based upon original research undertaken by the authors and that the paper were conceived and written by the authors alone and has not been published elsewhere. All information and ideas from others is referenced. 